Proc. Indian Acad. Sci. (Earth Planet. Sci.), Vol. 103, No. 1, March 1994, pp. 47-55.

(C) Printed in India.

\title{
Seasonal variation in temperature and salinity in the Gautami-Godavari estuary
}

\author{
B S R REDDY and V RANGA RAO \\ Department of Meteorology and Oceanography, Andhra University, Visakhapatnam \\ 530003 . India \\ MS received 4 December 1993; revised 16 March 1994
}

\begin{abstract}
Variation of temperature and salinity in the lower $22 \mathrm{~km}$ stretch of the GautamiGodavari estuary are reported during four different seasons; hot-weather, south-west monsoon, post-monsoon and winter seasons. The seasonal variation in temperature is small, with a high of about $30^{\circ} \mathrm{C}$ during hot-weather season and a low of about $26^{\circ} \mathrm{C}$ during winter season. Unlike temperatures, the salinities in the estuary show large seasonal fluctuations. During south-west monsoon surface salinities were low $(0$ to $8 \%$ ) due to high fresh water run off into the estuary. During hot-weather season surface salinities of 25 to $30 \%$ were observed due to negligible fresh water run off.
\end{abstract}

Keywords. Gautami-Godavari estuary; temperature; salinity; annual variations; seasonal variations.

\section{Introduction}

Seasonal variation in temperature and salinity in estuaries has been studied by a number of workers (Milne 1938; Bousefield 1955; Dyer and Ramamoorthy 1969; Gole and Vaidyaraman 1969; Reddy 1975; Qasim and Sengupta 1981; Beckett et al 1982 etc.). Some information on distribution of temperature, salinity, nutrients, currents etc. in the Gautami-Godavari estuary has been reported earlier by Ramasarma (1965). The river course and the flow of the Godavari estuary have changed since then (Ranga Rao 1991). Distribution variations of temperature, salinity and currents in the Gautami-Godavari estuary during July and January have been reported earlier by Ranga Rao et al (1988). In the present paper we report details of distribution of temperature and salinity during four different seasons, namely hot-weather season (March to May), south-west monsoon season (June to September), post-monsoon season (October to November) and winter season (December to February).

\section{Materials and methods}

The Godavari is the largest river in south India with a drainage basin of about $3 \times 10^{5} \mathrm{~km}^{2}$ (Rao 1975). The section of the estuary (figure 1) investigated for the present study is the lowermost $22 \mathrm{~km}$ of Bhiravapalem (where the Gautami-Godavari flowing east opens into the Bay of Bengal) branch which has an average width of about $1 \mathrm{~km}$ and depth of about $12 \mathrm{~m}$. The normal tidal range in the estuary is about $1 \mathrm{~m}$. The fresh water run off of Godavari river is mainly dependent on the monsoons. 


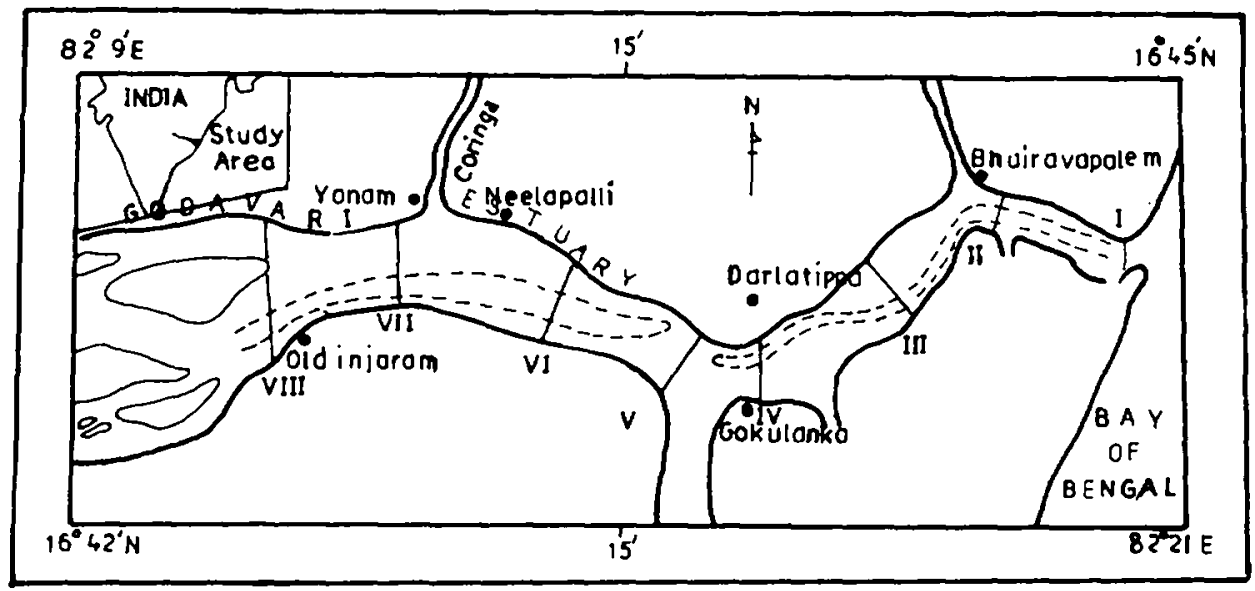

Figure 1. Godavari estuary with station locations (broken lines represent deep water areas).

It is maximum during June to October when the south-west monsoon prevails, and is minimum during January-May.

Temperature and salinity data were collected at eight stations (figure 1) starting from the mouth of the estuary to a distance of about $22 \mathrm{~km}$ upstream. To obtain a virtually instantaneous picture of the distribution of these parameters within the estuary at different times during a tidal cycle, eight stations were visited in sequence throughout the tidal cycle. For this, a procedure similar to the one adopted by Dyer and Ramamoorthy (1969) has been followed. The stations were divided into two groups of five to be observed on consecutive days, with the central two stations (stations IV and V) visited on both days. Stations I to $V$ were visited on one day and stations IV to VIII visited on the next day. Table 1 gives the dates and time when observations were carried out during each month. Each station was occupied atleast 6 times during the 13 hour period and measurements were made at every $2 \mathrm{~m}$ depth intervals from surface to bottom to obtain vertical profiles of parameters. Interpolation between measurements provided the instantaneous distribution of any parameter and changes, if any, over 2-day period becomes apparent because of measurements at 2 overlapping stations (stations IV and V). All measurements were carried out along the central axis of the channel during the time of spring tide period. This type of data collection was carried out at monthly intervals during the period May 1986 to July 1987 except during August 1986 and March 1987. Temperature and salinity were measured with portable in situ temperature-salinity recorder (EMCON model). Temperature could be read with an accuracy of $\pm 0.02^{\circ} \mathrm{C}$ and salinity with an accuracy of $\pm 0.1 \%$. The river discharge data from Godavari Head works Division, Dowlaiswaram was used. To obtain mean values reported in figure 2, salinity and temperature data for each month have been averaged. For fixing the time of high/low water for different stations graduated bamboo poles were fixed at the bank of the river near each station and the water levels were noted at 30 minute intervals. The time at which the water level reaches maximum (minimum) at each station is taken as high (low) water time for that station. Salinity during high/low water was determined by interpolation. 


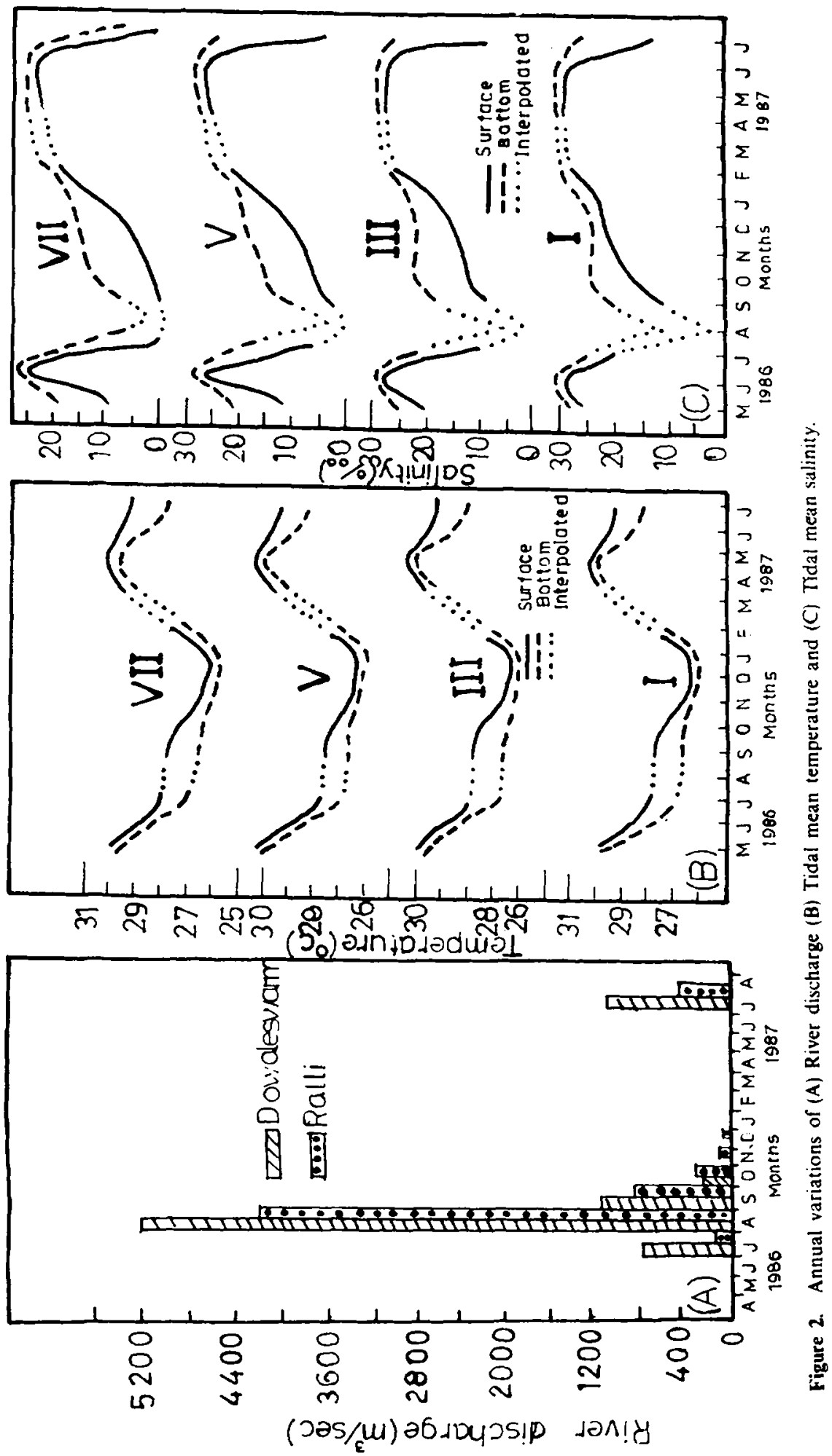


Table 1. Dates of data collection. On each day noted in the table the observations were carried out between $0500-1800$ hrs.

\begin{tabular}{lccc}
\hline Dates & $\begin{array}{c}\text { High water } \\
\text { time }\end{array}$ & $\begin{array}{c}\text { Low water } \\
\text { time }\end{array}$ & $\begin{array}{c}\text { Stations } \\
\text { visited }\end{array}$ \\
\hline 2 July 1986 & 0530 & 1200 & I to VIII \\
6 Sept. 1986 & 1000 & 1600 & I to V \\
7 Sept. 1986 & 1030 & 1700 & IV to VIII \\
17 Oct. 1986 & 0830 & 1430 & I to V \\
18 Oct. 1986 & 0900 & 1500 & IV to VIII \\
17 Nov. 1986 & 0900 & 1500 & I to V \\
18 Nov. 1986 & 0930 & 1530 & IV to VIII \\
14 Dec. 1986 & 0730 & 1330 & I to V \\
15 Dec. 1986 & 0800 & 1400 & IV to VIII \\
18 Jan. 1987 & 1030 & 1630 & I to VIII \\
27 Feb. 1987 & 0830 & 1430 & I to V \\
28 Feb. 1987 & 0900 & 1500 & V to VIII \\
15 Apr. 1987 & 0930 & 1600 & I to V \\
16 Apr. 1987 & 1000 & 1630 & IV to VIII \\
13 May 1987 & 0830 & 1500 & I to V \\
14 May 1987 & 0900 & 1530 & IV to VIII \\
14 June 1987 & 1030 & 1700 & I to V \\
15 June 1987 & 1100 & 1800 & IV to VIII \\
24 July 1987 & 0800 & 1430 & I to V \\
25 July 1987 & 0830 & 1530 & IV to VIII \\
\hline
\end{tabular}

\section{Results and discussions}

\subsection{Annual cycle}

The annual cycle of river discharge and mean temperature at the surface and bottom for different stations (I, III, V, and VII) are presented in figure 2. The temperature curve (figure 2B) indicates that maximum surface temperatures (about $30^{\circ} \mathrm{C}$ ) are found in May and minimum surface temperatures (about $26^{\circ} \mathrm{C}$ ) occur during winter months i.e., December and January. Similar behaviour is seen in the bottom temperatures. The annual range in temperature at the surface (bottom) is about $4^{\circ} \mathrm{C}\left(3.5^{\circ} \mathrm{C}\right)$. The bottom waters are cooler than the surface waters in general. The surface-bottom temperature difference is maximum from July to October $\left(1^{\circ} \mathrm{C}\right.$ to $\left.1.5^{\circ} \mathrm{C}\right)$ when there is fresh water discharge.

The annual variation of salinity (figure $2 B$ ) is large at all stations. The salinities are highest during dry pre-monsoon period (March to May) and lowest during monsoon period (July to September). The bottom salinities are higher than the surface salinities. The surface to bottom salinity difference is highest during July to December when there is large river discharge. Unlike temperatures, the salinity values show marked variation from station to station, and decrease from station I (near the mouth) to station VII (near the head). In a year the maximum surface salinity at station $I$ is about $30 \%$ while at station VII it is about $26.4 \%$. The minimum surface salinity at station I is about 12 while at station VII it is almost zero (in the months of July and 


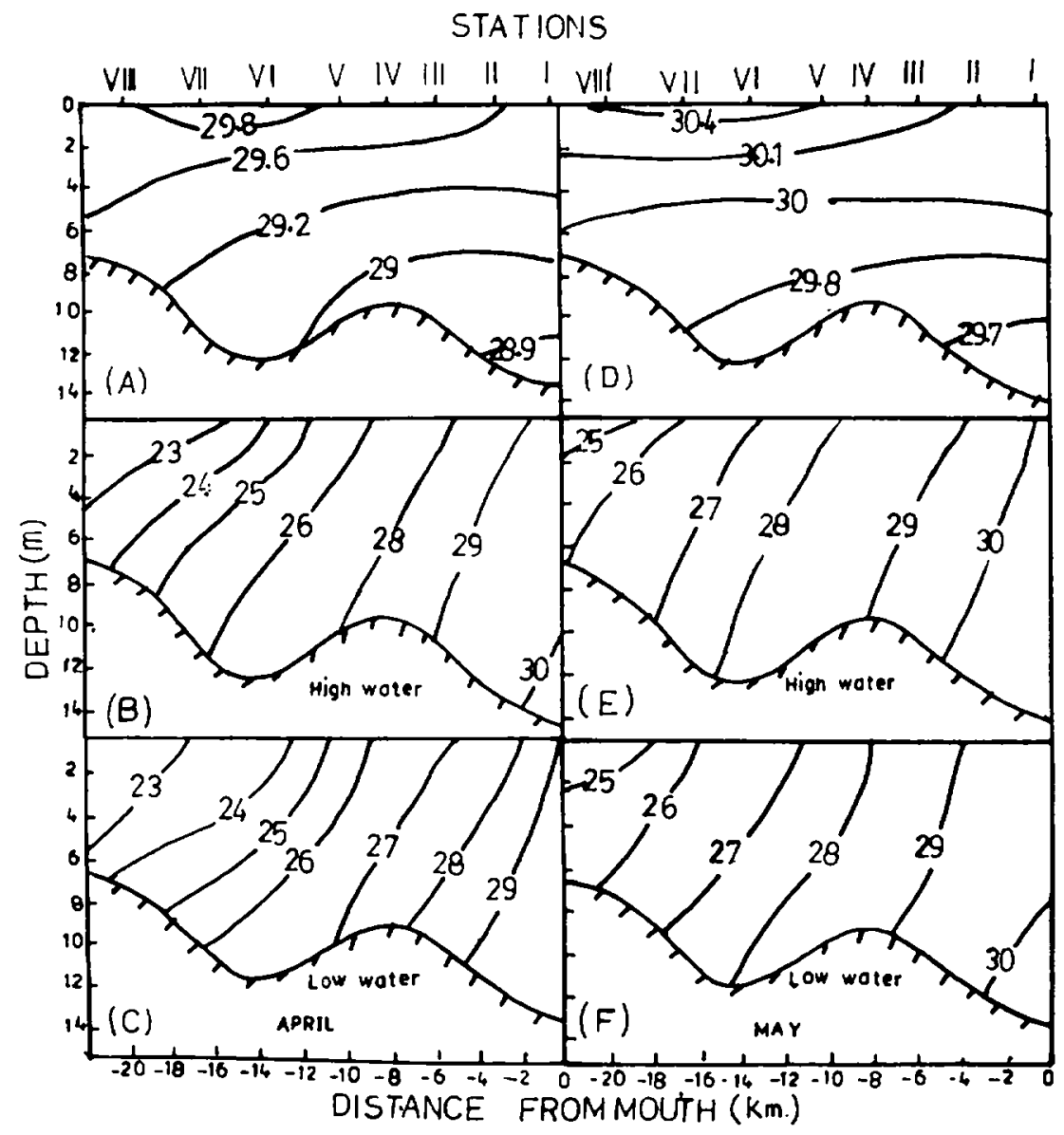

Figure 3. Longitudinal distribution of temperature and salinity during hot-weather season.

September). At bottom the maximum salinity in a year is about $31 \%_{0}$ at station I (June) while the minimum is about $10 \%$ at station VII (September). The surface to bottom salinity difference shows an increasing trend as one moves upstream towards the head of the estuary. A maximum surface to bottom salinity difference of about $12 \%$ at station VII (in October) and a minimum of about $0.5 \%$ at station I (June) were observed.

\subsection{Seasonal distribution}

During hot-weather season (March-May, figure 3) temperatures are high, and its vertical gradient is small possibly due to the intense tidal mixing. The salinity during this season increases from March to May with decreasing fresh water discharge. The salinities at all levels decrease away from the mouth even though the fresh water discharge is negligible. This suggests that the tidal mixing at the head is much less compared to that at the mouth of the estuary. 


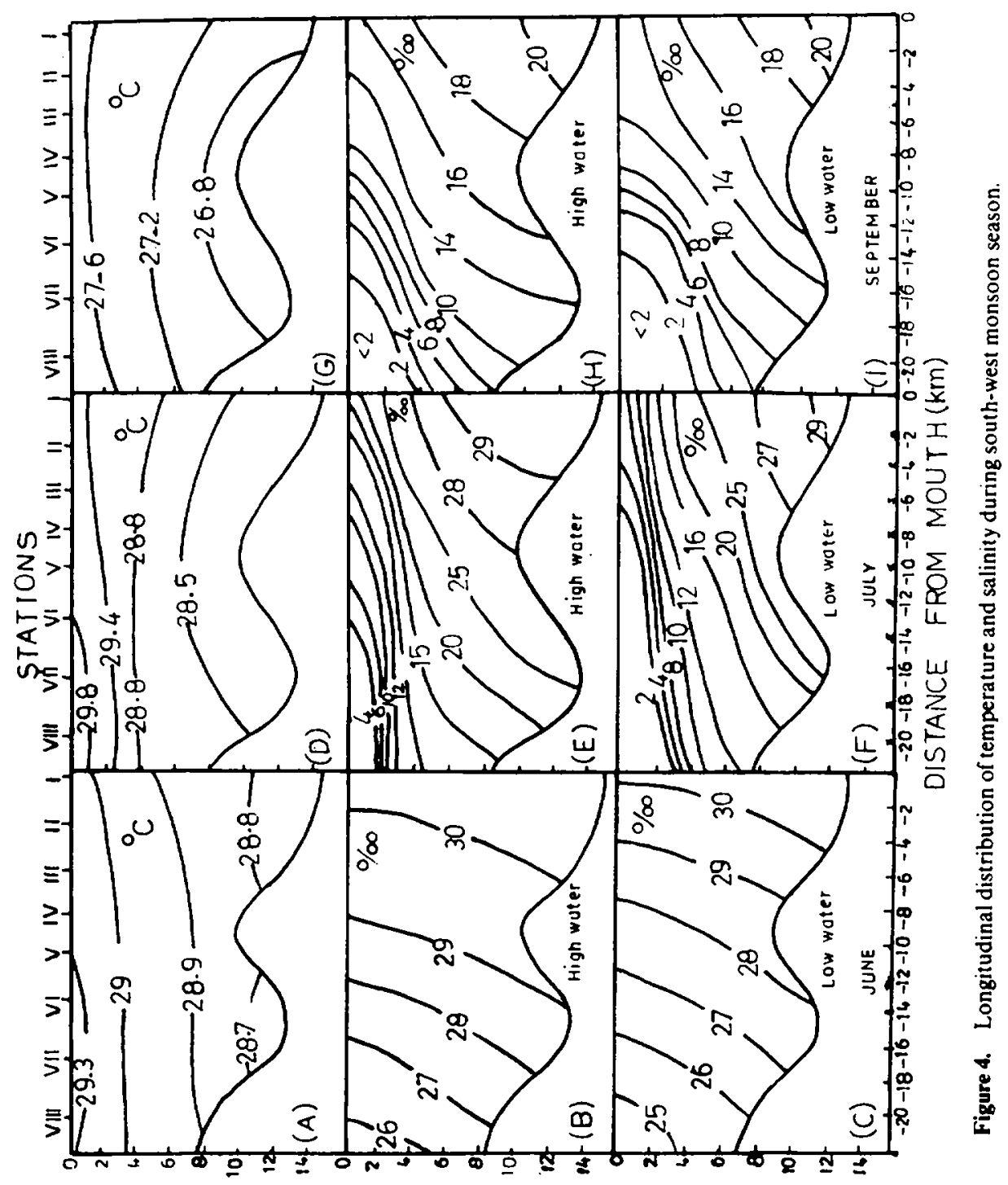

(w) H $1 d \exists J$ 


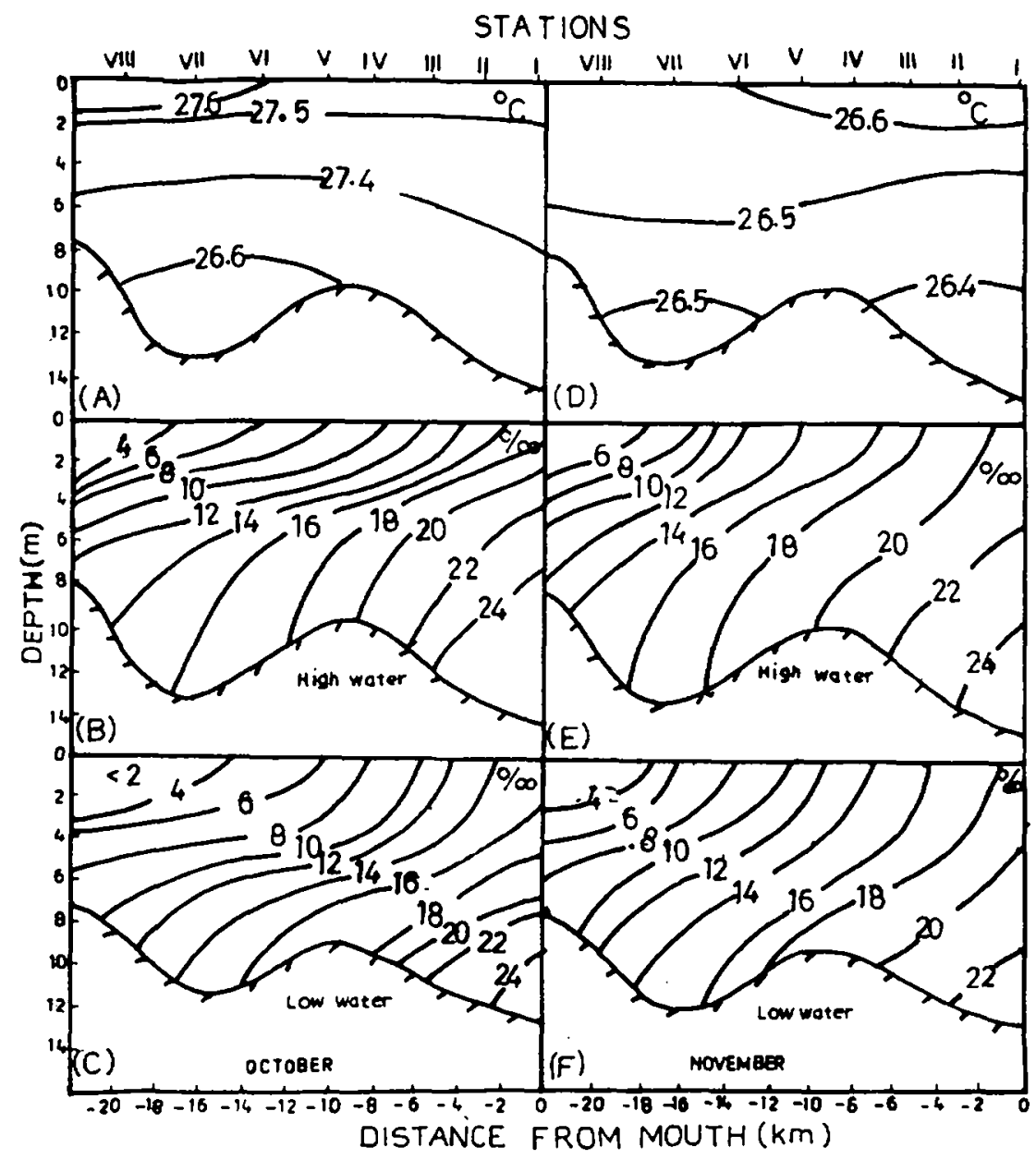

Figure 5. Longitudinal distribution of temperature and salinity during post-monsoon season.

In the south-west monsoon season (June-September, figure 4) the average temperature is much less than that during the hot-weather season. The estuary gets stratified by July when the river water starts flooding the estuary. It is possible that the entire estuary would be filled with the river water during August when the discharge is maximum. By September the stratification decreases due to decrease in the river discharge.

During post-monsoon season (October-November, figure 5) there is a gradual increase in salinity at all levels due to the decrease in the river discharge. The temperature of the estuarine waters decreased during this season in response to cooler atmospheric temperatures.

In winter season (December-February, figure 6) the temperature of estuarine waters is low because of the low atmospheric temperatures. From December the water temperature at all levels decreased and by January the temperatures reached a 


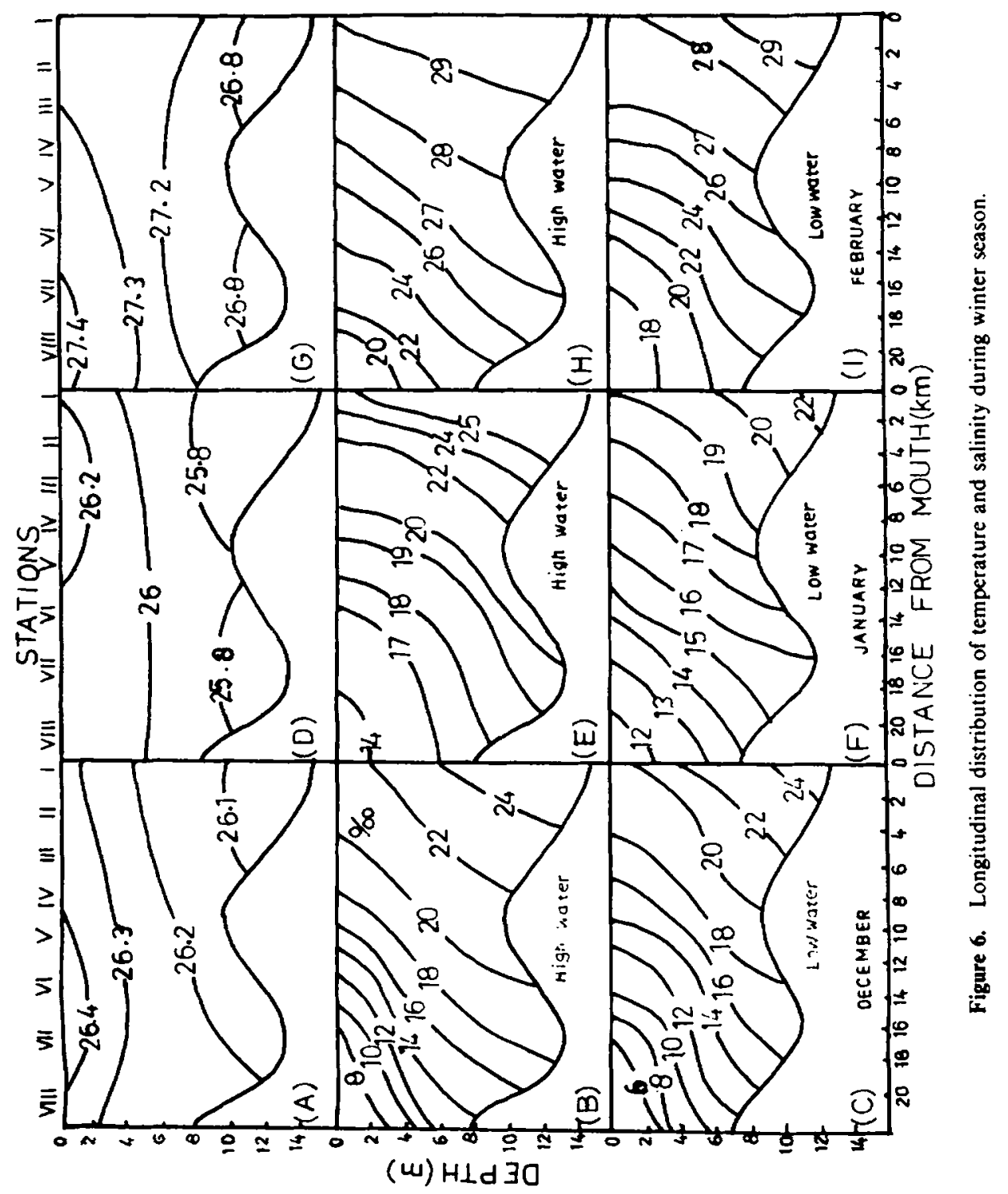


minimum. The salinities increased from December to February, implying increased intrusion of sea water into the estuary under conditions of low fresh water discharge.

\section{Acknowledgement}

One of the authors (V Ranga Rao) expresses sincere gratitude to the CSIR, New Delhi for the award of a Research Associate Fellowship during the period of this study.

\section{References}

Beckett R, Eastom A K, Hart B T and McKelvie I D 1982 The water movement and salinity in the Yara and Marybyrong estuaries; Aust. J. Mar. Freshwater Res. 33 401-420

Bousefield E L 1955 Some physical features of the Miramichi estuary; J. Fish. Res. Board, Canada 12 342-350

Dyer K R and Ramamoorthy K 1969 Salinity and water circulation in the Vellar estuary; Limnol. Oceanogr. 14 4-15

Gole C V and Vaidyaraman P P 1969 Salinity distribution and effect of fresh water flows in the Hoogly estuary; Coast. Eng. $101412-1422$

Milne A 1938 The ecology of the Tamar estuary, Vol III, Salinity and temperature conditions; J. Mar. Biol. Assoc., UK 22 529-539

Qasim S Z and Sengupta R 1981 Environmental characteristics of the Mandovi-Zuari estuarine system in Goa; Estuarine Coastal Shelf Sci. 13 557-578

Ramasarma D V 1965 Hydrography of the Gautami-Godavari estuary, Ph.D thesis, Andhra University

Ranga Rao V, Ramana Y V and Reddy B S R 1988 Salinity and current distribution in the Godavari estuary, East Coast of India; Indian J. Mar. Sci. 17 14-18

Ranga Rao V 1991 Some studies on the dynamics and physical features of the Godavari estuary, East Coast of India; Ph.D thesis, Andhra University

Rao K L 1975 India's water wealth, Orient Longman Ltd

Reddy B S R 1975 Oceanographic studies in the neighbourhood of a barrier beach near Kakinada bay; Ph.D thesis, Andhra University 